\title{
STRATEGI PEMENUHAN SYARAT MUTU STANDAR NASIONAL INDONESIA (SNI) BIJI KAKAO FERMENTASI
}

\section{Strategy to Fulfill Quality Requirements of Indonesian National Standard (SNI) of Fermented Cocoa Beans}

\author{
Fadlianto Botutihe, Mimin Yulita Kusumaningrum, Nicolays Jambang \\ Balai Pengkajian Teknologi Pertanian Papua Barat, Jln. Trikora Anday Kompleks Kawasan Terpadu \\ Kementerian Pertanian, Manokwari, Papua Barat, 98315, Telpon/Faksimili: 0986-2213347 \\ *Penulis Korespondensi, email: fadliantob@gmail.com
}

Disubmit: 16 April 2020 Direvisi: 23 Juni 2020 Diterima: 14 Desember 2020

\begin{abstract}
ABSTRAK
Hubungan atribut mutu biji kakao fermentasi dengan Standar Nasional Indonesia serta tahapan dan prioritas pengolahannya perlu dituangkan dalam suatu matriks. Penelitian ini bertujuan untuk mendeskripsikan hubungan atribut mutu biji kakao fermentasi yang dipersyaratkan SNI 2323-2008 dan tahapan pengolahannya dengan metode Quality Function Deployment (QFD), sehingga menghasilkan urutan prioritas tahapan pemrosesan. Penelitian ini terdiri dari 5 langkah, yaitu menyusun atribut kualitas, menyusun atribut proses produksi, menghubungkan atribut kualitas dan atribut tahapan pengolahan, menghubungkan tahapan pengolahan, sertamenghitung dan memilah tahapan prioritas pengolahan. Hasil penelitian menunjukkan bahwa hubungan yang sangat kuat terdapat pada atribut mutu pengotor memiliki nilai hubungan sebesar 3,8 dengan proses pengeringan biji kakao, kadar biji berjamur memiliki nilai hubungan sebesar 3,8 dengan penyimpanan biji kakao, kadar air memiliki nilai hubungan sebesar 3,6 dengan penyimpanan dan 4 dengan pengeringan biji kakao, serangga hidup memiliki nilai hubungan sebesar 3,8 dengan penyimpanan dan 3,6 dengan kemasan biji kakao. Hubungan yang erat antara pengolahan biji kakao ditunjukkan pada proses pengeringan memiliki nilai 3 dengan fermentasi biji kakao, biji kakao kering kemasan memiliki nilai 2,8 dengan pengeringan dan memiliki nilai 2,6 dengan sortasi biji kakao kering, kakao penyimpanan biji memiliki nilai hubungan 2,8 dengan pengeringan, dan memiliki nilai hubungan 2,6 dengan pemilahan biji kering dan memiliki nilai hubungan 3 dengan kemasan
\end{abstract}

Kata kunci : Biji Kakao; Fermentasi; Pascapanen; Prioritas; Pengolahan

\begin{abstract}
The relationship of the quality attributes of fermented cocoa beans in the Indonesian National Standard and its processing steps and priorities needs to be spelled out in a matrix. This study aims to describe the relationship between the quality attributes of fermented cocoa beans required by SNI 2323-2008 and the processing stages using the Quality Function Deployment (QFD) method, to produce a priority sequence of processing stages. This research consists of 5 steps, including arranging quality attributes, arranging the attributes of the production process, connecting quality attributes and processing step attributes, connecting the processing steps, and calculating and sorting the priority stages of processing. The results shown that a very strong relationship is in the attributes of the quality of impurities has a relationship value of 3.8 with the drying process of cocoa beans, moldy seed content has a relationship value of 3.8 with the storage of cocoa beans, water content has a relationship value of 3.6 with storage and 4 with drying cocoa beans, live insects have a relationship value of 3.8 with storage and by 3.6 with the packaging of cocoa beans. A strong relationship between cocoa bean processing is shown in the drying process has a value of 3 with the fermentation of cocoa beans, dried cocoa bean packaging has a value of 2.8 with drying and has a value of 2.6 with a sortation of dried cocoa beans, cocoa bean storage has a relationship value of 2.8 with drying, and has a relationship value of 2.6 with dry seed sortation and has a relationship value of 3 with packaging.
\end{abstract}


Jurnal Teknologi Pertanian Vol. 21 No. 3 [Desember 2020] 191-202

Strategi Pemenuhan Syarat Mutu Standar Nasional Indonesia (SNI) Biji Kakao Fermentasi [Botutihe dkk]

The results of the priority sequence analysis of the processing stages showed that cocoa bean storage had an average contribution value of 0.130 , drying cocoa beans had an average contribution value of 0.120 , and packaging had an average contribution value of 0.112 , soo that the strategy to fulfill SNI for cocoa bean fermentation can be optimal by using the QFD matrix

Keywords : Cocoa Beans; Fermentation; Postharvest; Processing; Priority

\section{PENDAHULUAN}

Rendahnya mutu biji kakao Indonesia dipengaruhi oleh hama gudang, kotoran, jamur, dan benda-benda asing lainnya (Kementerian Perdagangan, 2015). Terdapat dua indikator rendahnya mutu biji kakao Indonesia khususnya biji kakao rakyat yaitu biji kakao tidak difermentasi dan mengandung kotoran yang cukup tinggi. Menurut Sabahannur et al. (2016), sekitar 70\% produksi biji kakao dalam negeri belum memenuhi Standar Nasional Indonesia (SNI) karena teknologi pengolahan biji kakao yang belum dilakukan dengan baik dan benar.

Salah satu permasalahan yang dihadapi dalam upaya pengembangan kakao di Indonesia adalah kesadaran terhadap mutu produk yang dihasilkan dan mutu produksi masih rendah, belum semuanya diproses dengan cara fermentasi (Nurhadi et al., 2019). Menurut Amran et al. (2018), petani mengolah biji kakao belum sesuai dengan standar prosedur operasional fermentasi, sehingga biji kakao kurang bermutu. Biji kakao fermentasi yang bermutu sesuai dengan Standar Nasional Indonesia akan berdampak pada nilai ekonominya, dan bukan hanya bergantung pada varietas dan lingkungan dimana kakao tersebut dibudidayakan, tetapi juga lebih kepada bagaimana para petani kakao mengolah biji kakao fermentasi tersebut (Manalu, 2018).

Mutu biji kakao fermentasi dipengaruhi oleh sejumlah tahapan proses pengolahannya. Beberapa tahapan pengolahan yang mempengaruhi mutu dari biji kakao sesuai yang dipersyaratkan oleh SNI seperti pemanenan buah yang memiliki tingkat kematangan yang tinggi, agar tidak mempengaruhi jumlah biji kakao yang berkecambah, sehingga kadar lemak biji dapat menurun (Laxiana dan Sugiarto, 2018), kotoran (waste), dan benda-benda asing yang terdapat pada biji kakao. Selain itu juga dipengaruhi oleh beberapa tahapan pengolahan yaitu pada saat buah kakao dipecahkan, sortasi biji kakao basah, serta pengeringan (Sabahannur et al., 2016).
Pada Standar Nasional Indonesia (SNI 2323-2008) juga disebutkan beberapa persyaratan seperti kadar air, kadar biji berserangga, dan kadar biji kakao berjamur. Atribut mutu ini saling memilliki keterkaitan, begitupun dengan proses pengolahannya. Menurut Ariyanti (2017), bahwa kadar air pada biji kakao fermentasi dipengaruhi oleh lama waktu fermentasi, pengeringan, serta penyimpanan biji kakao tersebut. Proses fermentasi akan mempermudah pengeringan dan menghancurkan lapisan pulp yang menlekat pada biji (David dan Manurung, 2014). Oleh karenanya, semakin lama waktu fermentasi, maka kadar air biji kakao yang dihasilkan semakin rendah (Ariyanti, 2017). Menurut Hayati et al. (2012), biji kakao yang dikeringkan menggunakan suhu yang terlalu tinggi akan menyebabkan biji kakao tidak kering merata. Masih tingginya kadar air pada biji kakao akan menimbulkan bau asing yang dipengaruhi oleh jamur dan serangga. Proses fermentasi yang tidak sempurna (terdapat warna ungu agak keabu-abuan) akan mengakibatkan rendahnya mutu biji kakao (Ariyanti, 2017).

Upaya peningkatan dan perbaikan mutu biji kakao fermentasi telah banyak dilakukan melalui penelitian berupa analisis karakteristik mutu dan pengolahan, inovasi teknologi pengolahan, strategi daya saing dan kebijakan peningkatan mutu dan standar ekspor. Beberapa hasil penelitian terkait dengan strategi peningkatan mutu biji kakao yaitu fasilitasi infrastruktur pengujian mutu dan standar, fasilitasi regulasi, fasilitasi kerjasama harmonisasi mutu dan standar internasional, fasilitasi hambatan biaya dalam rangka peningkatan mutu dan standar, fasilitasi kemudahan prosedur dan mekanisme peningkatan mutu dan standar (Widyastutik dan Arianti, 2013), peningkatan mutu biji kakao melalui teknologi biopres pemerasan pulp (depulping) secara mekanis (Sumanto et al., 2015). Selanjutnya, menurut Sri Mulato (2019), bahwa peningkatan mutu dapat dilakukan dengan cara pengolahan biji kakao 
secara berkelompok di Unit Pengolahan Hasil (UHP) serta transformasi sikap mental dari budaya usaha "tradisionil" menuju budaya "industrial".

Strategi-strategi peningkatan mutu biji kakao fermentasi yang telah disebutkan sebelumnya, belum menjelaskan secara khusus peningkatan mutu berdasarkan tahapan pengolahan biji kakao untuk memenuhi Standar Nasional Indonesia. Keterkaitan atribut mutu biji kakao fermentasi dengan tahapan pengolahannya serta hubungan antar tahapan pengolahan biji kakao fermentasi yang mempengaruhi mutunya perlu dijabarkan dalam suatu matriks, sehingga diharapkan keterkaitan antara mutu dan tahapan pengolahannya akan mudah dipahami. Selain informasi keterkaitannya, matriks ini dapat juga memberikan informasi tambahan, yaitu urutan prioritas tahapan pengolahan untuk menghasilkan biji kakao fermentasi bermutu sesuai dengan atribut mutu yang dipersyaratkan.

Matriks yang dapat digunakan untuk menggambarkan hubungan keduanya adalah House of Quality (HoQ). Matriks ini sering digunakan dalam metode Quality Function Deployment (QFD). Metode lain yang dapat digunakan dalam peningkatan mutu produk dan pengendalian proses produksi adalah Six Sigma. Metode ini merupakan suatu proses peningkatan kualitas menuju target kemungkinan cacat 3,4 buah dalam satu juta produk/jasa. Six Sigma juga digunakan untuk mengurangi cacat (defect) dan memberikan kepuasan konsumen pada produk. Target utama dari Six Sigma adalah pengurangan variasi proses produksi (Latief et al., 2017). Akan tetapi, metode ini tidak didasarkan dari apa yang diinginkan dan dibutuhkan kosumen dalam peningkatan mutu suatu produk serta menerjemahkannya ke dalam proses produksi, sehingga kepuasan pelanggan yang dimaksud pada metode Six Sigma adalah kepuasan pelanggan terhadap mutu produk perspektif produsen. Menurut Afriyadi (2017) bahwa metode QFD bertujuan untuk memastikan bahwa kebutuhan dan keinginan konsumen dapat terpenuhi dengan baik. Metode ini sering menggunakan HoQ atau rumah kualitas untuk menampilkan keinginan atau kebutuhan konsumen, serta karakteristik teknis yang dibuat oleh perancang untuk memenuhi keinginan dan kebutuhan konsumen tersebut. Matriks HoQ menunjukkan hubungan antara kebutuhan-kebutuhan pelanggan dengan sifatsifat rekayasa teknik. Menurut Kurnianto et al. (2013), metode QFD dapat menerjemahkan keinginan konsumen (whats) ke dalam proses atau tahapan pengolahan serta dapat mengurutkan prioritas tahapan proses atau pengolahan, sehingga, peningkatan mutu suatu produk benar-benar berdasarkan mutu sesuai dengan perspektif konsumen.

Kelebihan penggunaan QFD untuk pengembangan produk pangan adalah mengurangi biaya dan waktu pengembangan produk (Dursun dan Karsak, 2013), meningkatkan peluang keberhasilan produk, menghasilkan produk pangan yang berkualitas tinggi (Suryaningrat, 2016). Penerapan metode QFD pada peningkatan mutu biji kakao fermentasi kemungkinan masih sedikit dan atau belum dilakukan. Penerapan metode QFD pada penelitian terkait tentang pangan kebanyakan hanya pada produk sekunder, salah satunya adalah penerapan metode QFD pada peningkatan kualitas produk coklat lokal. Hasil penelitian Anwar et al. (2015) menunjukan bahwa cita rasa, variasi rasa, tampilan dan informasi pada kemasan, dan kemudahan mendapatkan merupakan atribut yang diinginkan dan dibutuhkan konsumen serta respon teknis dari perusahaan untuk memenuhi kebutuhan konsumen tersebut di mulai dari sortasi buah dan biji kakao, proses pengolahan hingga proses pengemasan produk, juga upaya peningkatan promosi dan pemasaran produk.

Keinginan dan kebutuhan konsumen terhadap biji kakao fermentasi salah satunya adalah mutu yang melekat pada produk itu sendiri yang sesuai dengan Standar Nasional Indonesia. Oleh karenanya, pada penelitian ini, atribut mutu yang terdapat pada SNI baik persyaratan umum dan khusus digunakan sebagai input atau "whats" dalam tahap awal implemetasi metode QFD.

Tujuan dari penelitian ini adalah untuk menjabarkan hubungan atribut mutu biji kakao fermentasi yang dipersyaratkan oleh SNI 2323-2008 dan tahapan proses pengolahannya, hubungan antar proses pengolahan biji kakao fermentasi, serta urutan prioritas tahapan proses pengolahan biji kakao fermentasi menggunakan metode Quality Function Deployment (QFD). 
Jurnal Teknologi Pertanian Vol. 21 No. 3 [Desember 2020] 191-202

Strategi Pemenuhan Syarat Mutu Standar Nasional Indonesia (SNI) Biji Kakao Fermentasi [Botutihe dkk]

\section{METODE}

Pelaksanaan penelitian di Kabupaten Manokwari Selatan, Papua Barat pada bulan Februari sampai dengan bulan Maret. Penelitian ini untuk menjabarkan atribut mutu yang dipersyaratkan Standar Nasional Indonesia (SNI 2323-2008) ke dalam respon teknis (tahapan pengolahan) biji kakao fermentasi, mengkorelasikan hubungan tahapan pengolahan, serta prioritas tahapan pengolahannya.

Data yang digunakan dalam penelitian ini adalah data primer dan data sekunder. Data primer diperoleh dengan cara membagikan kuesioner tentang hubungan atribut mutu biji kakao fermentasi dengan tahap pengolahannya dan hubungan antara tahapan pengolahan biji kakao fermentasi kepada pakar bidang pascapanen, ilmu dan teknologi pangan, dan teknologi pangan menggunakan Google Form (https:/ / bit.ly/ formpenelitiankakao). Jumlah pakar yang dilibatkan dalam penelitian ini berjumlah 5 orang. Data sekunder diperoleh dari dokumen Standar Nasional Indonesia (SNI 23232008: Biji Kakao), serta studi literatur seperti buku, jurnal, dan majalah.

Analisis data penelitian ini didasarkan pada metode QFD. Adapun tahapan-tahapan yang dilakukan adalah menyusun matriks atribut mutu biji kakao fermentasi sesuai SNI 2323-2008, menyusun karakter teknis atau tahapan pengolahan biji kakao fermentasi, menyusun matriks kebutuhan hubungan antara atribut mutu dan tahapan pengolahan, menyusun matriks korelasi antara tahapan proses pengolahan, menghitung prioritas tahapan pengolahan dengan cara menghitung jumlah nilai hubungan pada setiap tahapan pengolahan, menghitung nilai kontribusi (persentase nilai prioritas suatu atribut tahapan pengolahan dari total jumlahnya), dan mengurutkan urutan prioritas tahapan pengolahan.

\section{HASIL DAN PEMBAHASAN}

\section{Atribut Mutu Biji Kakao Fermentasi}

Atribut mutu pada SNI (2323-2008) yaitu persyaratan umum dan khusus mutu biji kakao yang disajikan pada Tabel 1 dan Tabel 2, dijadikan sebagai input customer pada matriks keinginan dan kebutuhan konsumen. Hal ini untuk melihat sejauh mana masing-masing atribut dipengaruhi oleh respon teknis (tahapan pengolahan).

\section{Matriks House of Quality (HoQ) Biji Kakao Fermentasi}

Hasil analisis hubungan atribut mutu biji kakao yang dipersyaratkan oleh SNI 2323-2008 dan respon teknis (tahapan pengolahan), hubungan antar respon teknis dan urutan prioritas tahapan pengolahan ditunjukan pada matriks Quality Function Deployment (QFD) atau lebih dikenal dengan House of Quality (HoQ), yang ditunjukkan pada Gambar 1.

\section{Respon Teknis (Tahapan Pengolahan)}

Teknis yang digunakan untuk merespon atribut mutu biji kakao fermentasi pada matriks kebutuhan dan keinginan konsumen yaitu tahapan pengolahan. Pengggunaan tahapan pengolahan biji kakao dengan cara fermentasi memiliki banyak keunggulan. Menurut Sudjarmoko (2013), biji kakao yang diolah dengan cara fermentasi menimbulkan aroma, proses produksi lebih lancar, pasar Eropa dan Jepang $85 \%$, dan sebagai bahan baku utama. Pada biji kakao yang tidak diolah dengan cara fermentasi, biji kakao tidak beraroma, proses produksi menjadi lengket/ mampet, pasar USA, Singapura, dan Malaysia $(15 \%)$. Teknis yang digunakan untuk merespon atribut mutu biji kakao fermentasi pada matriks kebutuhan dan keinginan konsumen yaitu tahapan pengolahan biji kakao fermentasi. Adapun tahapannya disajikan pada Tabel 3.

\section{Hubungan Atribut Mutu Biji Kakao Fermentasi dan Tahapan Pengolahan}

Hasil dari penggunaan metode QFD pada hubungan antara atribut mutu dan tahapan pengolahan, menunjukkan atribut mutu kadar biji berkecambah yang memiliki hubungan kuat dengan proses pemanenan, pemeraman, atau penyimpanan buah kakao, fermentasi biji kakao, dan sortasi biji kakao basah. Hal ini diakibatkan oleh tingkat kematangan buah kakao. Menurut Marwati et al. (2012), tingkat kematangan buah mempengaruhi pada jumlah kadar biji berkecambah. Semakin tinggi tingkat kematangan buah, maka semakin cepat pula terjadinya pertumbuhan lembaga dan mempengaruhi perkecambahan biji kakao, apabila buah kakao tidak segera dipanen. Pada tahapan proses pengolahan yaitu pemeraman atau penyimpanan buah, kemungkinan biji buah kakao akan mengalami perkecambahan (Laxiana dan Sugiarto, 2018). Pemeraman cukup di- 
lakukan selama 5 hari dan tidak boleh lebih dari 12 hari untuk meminimalisir terjadinya perkecambahan biji (Iflah dan Towaha, 2015). Selanjutnya, jika tidak dilakukan tahapan sortasi biji basah, maka, biji kakao yang telah berkecambah yang tercampur dengan biji kakao yang tidak berkecambah akan masuk ke dalam proses selanjutnya. Pada proses fermentasi, lembaga di dalam biji kakao akan mati (David dan Manurung, 2014).

Hubungan atribut mutu yaitu kadar kotoran (waste) berhubungan kuat dengan pemecahan buah kakao, pengeringan biji kakao, sortasi biji kakao basah, pengemasan serta penyimpanan. Pada saat proses pemecahan buah kakao, banyak kotoran yang menempel pada buah dan biji kakao seperti kulit buah, daun, dan ranting, yang akan ikut pada proses fermentasi. Pada saat proses pengeringan, kotoran-kotoran yang berukuran kecil yang akan menempel pada biji kakao. Menurut Sabahannur et al. (2016), adanya kotoran pada biji kakao kemungkinan disebabkan oleh petani yang tidak melakukan pembersihan pada saat proses pengeringan. Kotoran yang telah menempel pada biji akan susah dibersihkan atau dipisahkan pada proses sortasi biji kering. Proses pengemasan dan penyimpanan dilakukan dalam tempat atau ruangan yang bersih untuk menghindari terjadinya kontaminasi fisik pada biji kakao.

Kadar biji slaty (biji tidak terfermentasi) berhubungan kuat dengan proses fermentasi yang singkat dan tidak sempurna, serta proses fermentasi yang terjadi secara tidak merata ke seluruh biji kakao, yang ditandai biji kakao berwarna ungu keabu-abuan (Ariyanti, 2017). Mutu kadar biji kakao berjamur berhubungan kuat dengan tahapan proses pemeraman atau penyimpanan buah kakao, pengeringan, sortasi biji kakao kering, pengemasan dan penyimpanan. Pada proses pemeraman yang tidak sempurna, dapat menyebabkan jamur akibat pembusukan buah yang dapat mencemari biji kakao pada berbagai tahapan pengolahan (Munarso, 2017; Laxiana dan Sugiarto, 2018). Kadar biji kakao berjamur berhubungan kuat juga dengan proses pengeringan. Pada proses pengeringan setelah tahap fermentasi, merupakan titik kritis pengendalian jamur dan produksi toksin (Munarso, 2017). Timbulnya jamur pada biji kakao berhubungan erat dengan kadar air di dalamnya. Menurut Ariyanti (2017), adanya kadar biji kakao berjamur kemungkinan disebabkan karena proses pen- geringan yang dilakukan tidak sempurna. Kadar air biji kakao tergantung pada metode pengeringan dan penyimpanan biji setelah proses fermentasi. Semakin tinggi kadar air biji kakao maka kemungkinan akan terjadinya penurunan mutu biji kakao karena munculnya jamur. Pemisahan atau sortasi biji kakao kering dari biji kakao yang berjamur sangatlah penting untuk mencegah terjadinya kontaminasi silang. Kemasan yang digunakan untuk biji kakao diusahakan memiliki sirkulasi udara yang baik dan disimpan pada tempat atau ruangan yang memiliki sirkulasi udara yang baik pula. Faktor yang penting dalam penyimpanan adalah kadar air bahan dan kelembaban udara tempat penyimpanan. Proses kerusakan bahan secara biologis, fisiologis, dan kimiawi selama penyimpanan membutuhkan air sebagai media (Dumadi, 2011).

Atribut mutu selanjutnya, yaitu kadar biji (persentase jumlah biji) berbau asap dan atau hummy dan atau berbau asing memiliki hubungan kuat dengan proses pengeringan, pengemasan, dan penyimpanan. Menurut Wajri dan Tamrin (2017), bahwa beberapa kasus proses pengeringan yang terjadi dimasyarakat ketika dalam keadaan musim hujan dan tidak memiliki alat pengeringan listrik, pengeringan biji kakao dilakukan dengan cara dikeringkan dengan menggunakan rumah asap. Proses pengeringan seperti ini akan menimbulkan bau asap pada biji kakao. Selain itu, proses pengeringan biji kakao dengan suhu yang terlalu tinggi akan mengakibatkan pengeringan tidak merata yaitu bagian dalam masih basah dan bagian luarnya kering (Hayati et al., 2012). Biji kakao kering yang masih mengandung banyak air akan mudah diserang oleh serangga. Hal tersebut akan menyebabkan biji kakao akan berbau asing selama proses penyimpanan karena adanya serangan jamur dan serangga (Ariyanti, 2017).

Tahapan pascapanen kakao yang terakhir adalah pengemasan dan penyimpanan. Pengemasan biji kakao kering harus menggunakan bahan kemasan yang bersih yang bukan bekas kemasan hasil pertanian yang memiliki aroma yang kuat atau bukan bekas pestisida, begitu juga dengan penyimpanan. Biji kakao kering diusahakan disimpan terpisah dengan hasil pertanian yang memiliki aroma yang tinggi. Hal ini karena kakao dapat meyerap bau yang disebabkan oleh tingginya lemak yang terkandung didalamnya. 
Tabel 1. Persyaratan umum biji kakao

\begin{tabular}{clcc}
\hline No & Jenis Uji & Satuan & Persyaratan \\
\hline 1 & Serangga hidup & - & Tidak ada \\
2 & Kadar air & \% fraksi massa & Maks. 7,5 \\
3 & Biji berbau asap dan atau hummy dan atau berbau asing & - & Tidak ada \\
4 & Kadar benda asing & - & Tidak ada \\
\hline Sumber : Badan Standardisasi Nasional, 2008
\end{tabular}

Tabel 2. Persyaratan khusus biji kakao

\begin{tabular}{|c|c|c|c|c|c|c|}
\hline \multicolumn{2}{|c|}{ Jenis Mutu } & \multicolumn{5}{|c|}{ Persyaratan } \\
\hline $\begin{array}{l}\text { Kakao } \\
\text { Mulia } \\
\text { (Fine } \\
\text { cocoa) }\end{array}$ & $\begin{array}{c}\text { Kakao } \\
\text { Lindak } \\
(\text { Bulk } \\
\text { cocoa })\end{array}$ & $\begin{array}{c}\text { Kadar } \\
\text { biji ber- } \\
\text { jamur } \\
\text { (biji/biji) }\end{array}$ & $\begin{array}{c}\text { Kadar } \\
\text { biji slaty } \\
\text { (Biji/biji) }\end{array}$ & $\begin{array}{c}\text { Kadar biji } \\
\text { berserangga } \\
\text { (biji/biji) }\end{array}$ & $\begin{array}{c}\text { Kadar } \\
\text { kotoran } \\
\text { (waste) } \\
\text { (biji/biji) }\end{array}$ & $\begin{array}{c}\text { Kadar biji } \\
\text { berkecambah } \\
\text { (biji/biji) }\end{array}$ \\
\hline I $-F$ & $I-B$ & Maks. 2 & Maks. 3 & Maks. 1 & Maks. 1,5 & Maks. 2 \\
\hline II - F & II $-B$ & Maks. 4 & Maks. 8 & Maks. 2 & Maks. 2,0 & Maks. 3 \\
\hline III - F & III - B & Maks. 4 & Maks. 20 & Maks. 2 & Maks. 3,0 & Maks. 3 \\
\hline
\end{tabular}

Keterangan: satuan dalam persen. Sumber : Badan Standardisasi Nasional, 2018

Tabel 3. Tahapan pengolahan biji kakao fermentasi

\begin{tabular}{|c|c|c|c|c|}
\hline No & Tahapan Pengolahan & & & \\
\hline 1 & Pemanenan buah kakao & & & \\
\hline 2 & Sortasi buah kakao & & & \\
\hline 3 & Pemeraman/penyimpanan buah kakao & & & \\
\hline 4 & Pemecahan buah kakao & & & \\
\hline 5 & Sortasi biji kakao basah & & & \\
\hline 6 & Fermentasi & & & \\
\hline 7 & Perendaman dan pencucian biji kakao & & & \\
\hline 8 & Pengeringan & & & \\
\hline 9 & Sortasi biji kakao kering & & & \\
\hline 10 & Pengemasan & & & \\
\hline 11 & Penyimpanan & & & \\
\hline \multicolumn{5}{|c|}{ Sumber: Tarigan dan Iflah (2017) } \\
\hline \multicolumn{5}{|c|}{ Tabel 4. Prioritas tahapan pengolahan } \\
\hline No & Tahapan Pengolahan & Prioritas & Kontribusi & Urutan Prioritas \\
\hline 1 & Pemanenan buah kakao & 13,00 & 0,063 & 11 \\
\hline 2 & Sortasi buah kakao & 12,80 & 0,062 & 9 \\
\hline 3 & Pemeraman/Penyimpanan buah kakao & 17,00 & 0,082 & 7 \\
\hline 4 & Pemecahan buah kakao & 18,40 & 0,089 & 6 \\
\hline 5 & Sortasi biji kakao basah & 13,40 & 0,065 & 10 \\
\hline 6 & Fermentasi biji kakao & 20,00 & 0,096 & 5 \\
\hline 7 & Perendaman dan pencucian biji kakao & 14,80 & 0,071 & 8 \\
\hline 8 & Pengeringan biji kakao & 25,00 & 0,12 & 2 \\
\hline 9 & Sortasi biji kakao kering & 22,00 & 0,106 & 4 \\
\hline 10 & Pengemasan biji kakao kering & 23,20 & 0,112 & 3 \\
\hline 11 & Penyimpanan biji kakao kering & 27,00 & 0,130 & 1 \\
\hline
\end{tabular}




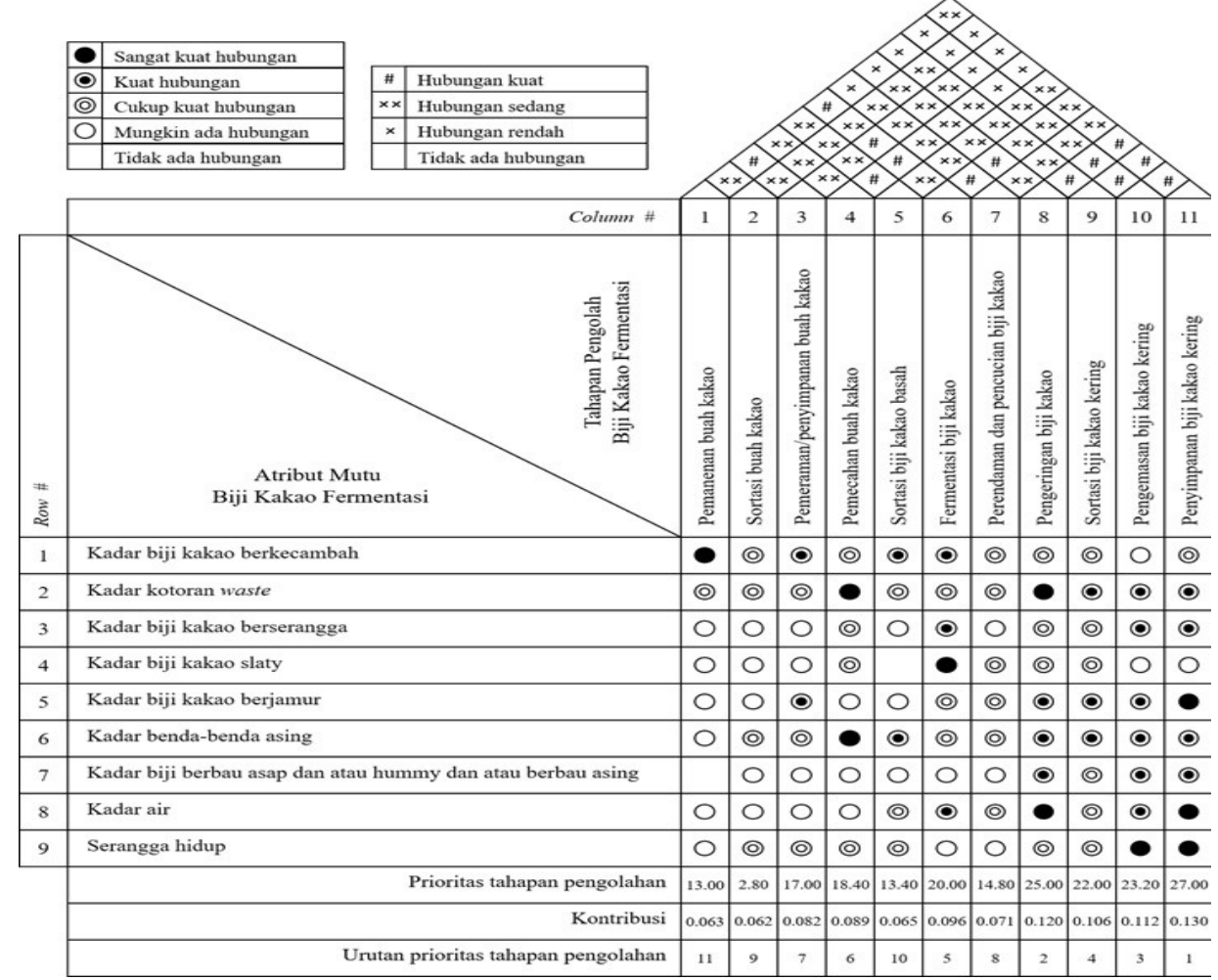

Gambar 1. Hubungan atribut mutu biji kakao fermentasi dan tahapan pengolahan

\begin{tabular}{|c|c|c|c|c|c|c|c|c|c|c|c|c|}
\hline & $\mathrm{Col}$ & 1 & 2 & 3 & 4 & 5 & 6 & 7 & 8 & 9 & 10 & 11 \\
\hline & $\begin{array}{l}\text { Atribut Mutu } \\
\text { Biji Kakao Fermentasi }\end{array}$ & 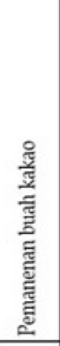 & 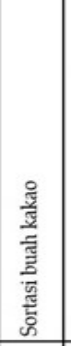 & 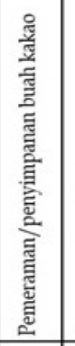 & 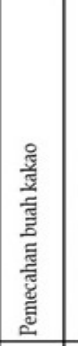 & 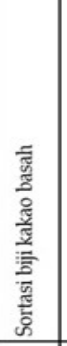 & 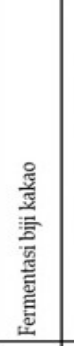 & 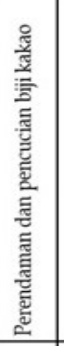 & 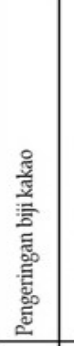 & 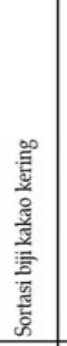 & 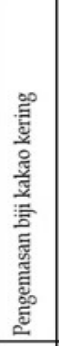 & 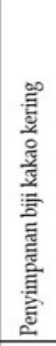 \\
\hline 1 & Kadar biji kakao berkecambah & $\bullet$ & (-) & 0 & (-) & 0 & 0 & () & (-) & () & 0 & (-) \\
\hline 2 & Kadar kotoran waste & (2) & (๑) & (2) & $\bullet$ & ๑) & (-) & () & - & $\circ$ & $\circ$ & 0 \\
\hline 3 & Kadar biji kakao berserangga & $\bigcirc$ & O & ○ & (๑) & O & ○ & O & (-) & (2) & ○ & $\circ$ \\
\hline 4 & Kadar biji kakao slaty & $\bigcirc$ & O & 0 & (-) & & $\bullet$ & (2) & (2) & (2) & $\bigcirc$ & O \\
\hline 5 & Kadar biji kakao berjamur & $O$ & ○ & 0 & 0 & 0 & () & (-) & ○ & 0 & 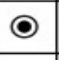 & 0 \\
\hline 6 & Kadar benda-benda asing & $\bigcirc$ & (2) & (2) & 0 & ○ & (2) & (๑) & O & 0 & ○ & ○ \\
\hline 7 & $\begin{array}{l}\text { Kadar biji berbau asap dan atau hummy } \\
\text { dan atau berbau asing }\end{array}$ & & O & O & O & O & O & O & ○ & ( ) & ○ & ○ \\
\hline 8 & Kadar air & $\bigcirc$ & O & O & O & (-) & ○ & (-) & - & (-) & $\circ$ & $\bullet$ \\
\hline 9 & Serangga hidup & 0 & (๑) & (2) & (2) & (2) & O & O & (2) & (2) & - & $\bullet$ \\
\hline & & & & & & & & & & & & \\
\hline & $\begin{array}{l}\text { gat kuat hubungan } \\
\text { lat hubungan }\end{array}$ & & & & & & & & & & & \\
\hline
\end{tabular}

Gambar 2. Hubungan atribut mutu biji kakao fermentasi dan tahapan pengolahan 
Menurut Dumadi (2011), bahwa syarat jenis kemasan harus dapat melindungi biji kakao selama pengangkutan. Jenis kemasan yang digunakan untuk pengemasan kakao dapat berupa karung goni dan atau karung goni yang dilapisi kantong plastik.

Kandungan kadar air berdasarkan syarat SNI (2323-2008) adalah kadar air biji kakao sebesar maksimal 7,5\%. Kadar air biji kakao kering berhubungan kuat dengan tahapan proses fermentasi, pengeringan, pengemasan, dan penyimpanan. Proses fermentasi akan menurunkan jumlah kadar air yang terdapat pada biji kakao. Menurut Ariyanti (2017), semakin lama waktu fermentasi, maka kadar air biji kakao yang dihasilkan semakin rendah. Pada proses pengeringan, seperti yang sudah dijelaskan sebelumnya, hubungan kadar biji kakao berjamur dengan proses pengeringan adalah titik kritis yang mempengaruhi jumlah kadar biji kakao berjamur. Oleh karenanya dapat disimpulkan bahwa kadar biji kakao berjamur memiliki hubungan berbanding lurus. Selain itu, pengeringan biji kakao setelah proses fermentasi, dengan menggunakan suhu yang terlalu tinggi dapat mengakibatkan pengeringan yang tidak merata yaitu bagian luar kering, sedangkan bagian dalam masih banyak mengandung air (David dan Manurung, 2014). Pengemasan yang baik untuk biji kakao kering menggunakan karung. Kemasan yang digunakan harus bersih, bukan bekas pestisida atau pupuk serta memiliki pori-pori, begitu pula dengan penyimpanannya, harus memiliki sirkulasi udara untuk keluar masuk udara untuk mencegah kelembaban yang tinggi (Ariyanti, 2017).

Atribut mutu biji kakao terakhir yaitu kadar serangga hidup. Terdapatnya serangga hidup pada biji kakao kering dipengaruhi oleh banyak faktor, mulai kakao difermentasi sampai pada proses penyimpanan. Biji kakao kering yang masih mengandung banyak air akan mudah diserang oleh serangga (Ariyanti, 2017). Hal ini disebabkan oleh lama waktu proses fermentasi, meningkatnya waktu fermentasi maka kadar air dalam biji kakao juga akan meningkat (Hayati et al., 2012). Selain itu, pada proses pengeringan, penggunaan suhu yang terlalu tinggi akan menyebabkan biji kakao tidak dapat mengering secara merata dan masih terdapat bagian biji kakao yang basa (Ariyanti, 2017).

Hasil penelitian menunjukan atribut kadar serangga memiliki hubungan sangat kuat dengan proses pengemasan dan penyimpanan biji kakao. Menurut Arief dan Asnawi (2011), bahwa kemasan dan tempat penyimpanan yang terdapat telur atau larva serangga yang semula tidak terlihat akan berkembang menjadi serangga dewasa saat biji kakao tersebut disimpan. Serangga pada bahan kemasan dan ruang penyimpanan akan mengontaminasi biji kakao. Kontaminasi oleh serangga umumnya terjadi di tempat penyimpanan.

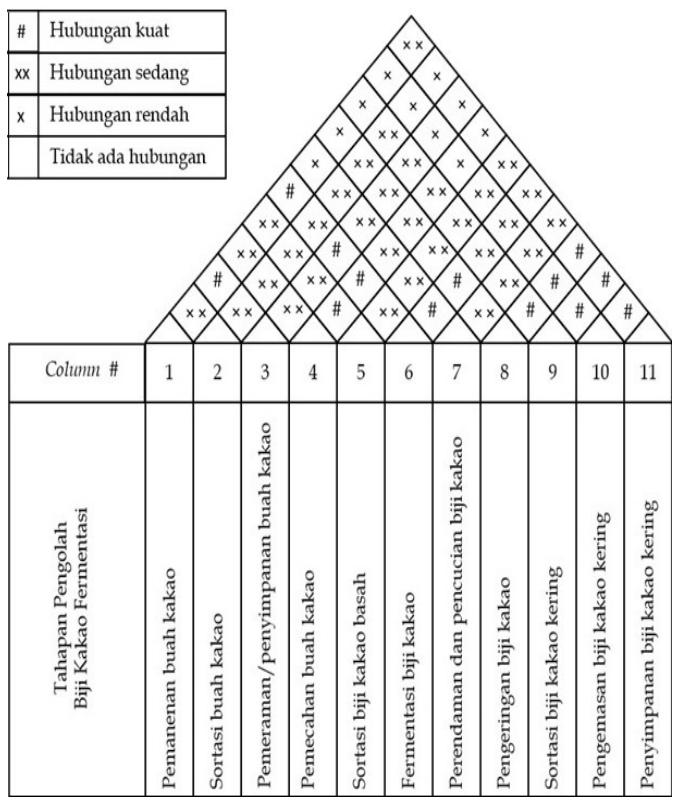

Gambar 3. Hubungan respon teknis (tahapan pengolahan) 


\section{Hubungan Tahapan Pengolahan Biji Kakao Fermentasi}

Hasil analisis menggunakan metode QFD pada hubungan antara tahapan pengolahan ditunjukkan pada Gambar 3, dimana setiap tahapan proses pengolahan biji kakao fermentasi saling memiliki hubungan dengan tingkat hubungan yang berbeda-beda. Pada penelitian ini, hanya akan dijelaskan tahapan pengolahan yang memiliki hubungan kuat.

Tahapan pengolahan pemanenan memiliki hubungan kuat dengan pemeraman atau penyimpanan buah kakao. Hal ini berkaitan dengan tujuan pemeraman yaitu untuk meningkatkan laju respirasi yang ditandai dengan produksi etilen yang akan berpengaruh pada tingkat kematangan buah, sehingga tingkat kematangan buah kakao lebih seragam (Iflah dan Towaha, 2015).

Proses pemeraman atau penyimpanan buah kakao berhubungan kuat dengan proses fermentasi biji kakao. Menurut Amran et al. (2018), pemeraman bertujuan untuk mempermudah pada saat biji kakao difermentasi, karena dengan proses pemeraman akan mengakibatkan pulp akan mudah terlepas dari biji kakao.

Pemecahan buah kakao memiliki hubungan kuat dengan proses fermentasi biji kakao. Biji kakao yang cacat atau pecah akibat proses pemecahan buah akan mengakibatkan biji cepat rusak dan membuka peluang terjadinya kontaminasi silang pada proses pengalahan selanjutnya. Menurut Utami (2018), buah yang pecah, busuk dan berulat dapat merusak biji sehingga mengganggu berlangsungnya proses fermentasi. Selain itu, pemecahan buah kakao juga memiliki hubungan kuat dengan sortasi biji basah kakao. Segera setelah buah kakao dipecahkan, dilakukan proses sortasi biji kakao basah. Hal ini bertujuan untuk memisahkan biji kakao yang berjamur dan berkecambah yang terjadi setelah proses pemeraman (Ariyanti, 2017). Saat pemecahan biji kakao basah banyak kotoran (kulit buah, daun, ranting) yang ikut masuk ke kotak fermentasi, sehingga butuh proses sortasi biji kakao basah. Menurut Laxiana dan Sugiarto (2018), pada proses pemeraman selama 10 hari, akan terjadi serangan jamur yang menyebabkan sekitar 15\% sampai 38\% biji berwarna hitam, yang kemungkinan diakibatkan oleh pembusukan buah karena pertumbuhan jamur, dan kemungkinan yang lain, yaitu terjadi perkecambahan biji.
Tahapan fermentasi biji kakao berhubungan kuat dengan pemanenan buah kakao, perendaman atau pencucian biji kakao setelah difermentasi, dan proses pengeringan biji kakao. Pada proses pemanenan buah kakao perlu memperhatikan tingkat kematangan buah. Menurut Iflah dan Towaha (2015), kematangan buah akan mempengaruhi aktivitas mikroorganisme, dan buah yang matang sempurna kandungan gula yang lebih tinggi, sehingga aktivitas mikroorganisme tinggi. Selanjutnya, pada proses perendaman atau pencucian biji kakao dapat menghentikan proses fermentasi (Amran et al., 2018). Pencucian bertujuan untuk menghentikan proses fermentasi, dan mempercepat proses pengeringan. Hubungan yang terjadi antara proses fermentasi dan pengeringan terdapat pada kemudahan pada saat proses pengeringan (David dan Manurung, 2014). Proses fermentasi akan mempermudah pengeringan dan menghancurkan lapisan pulp yang melekat pada biji. Hasil penelitian Marwati et al. (2012), biji kakao dengan tingkat kematangan paling rendah yakni buah yang kuning pada alur buah, dimana kandungan air yang terdapat pada biji kakao tersebut sebesar $8,90 \%$. Nilai kadar air terendah diperoleh pada buah dengan tingkat kematangan kuning tua pada seluruh permukaan buah, dimana nilai kadar airnya sebesar $6,25 \%$. Selanjutnya, menurut hasil penelitian Hayati et al. (2012), laju pengeringan yang tertinggi yaitu fermentasi 8 hari pada suhu $60{ }^{\circ} \mathrm{C}$ yaitu sebesar $1.32 \% \mathrm{bk} / \mathrm{jam}$ dan yang terendah tanpa fermentasi pada suhu $40{ }^{\circ} \mathrm{C}$ yaitu sebesar $0.39 \% \mathrm{bk} / \mathrm{jam}$. Hal ini terjadi karena semakin bertambahnya waktu, maka kadar air semakin menurun, sehingga menyebabkan laju pengeringan menurun pula.

Pengeringan biji kakao memiliki hubungan kuat dengan sortasi biji kakao kering, pengemasan, dan penyimpanan. Menurut David dan Manurung (2014), tujuan utama pengeringan biji kakao adalah mengurangi kadar air biji dari $60 \%$ menjadi 6-7\% sehingga aman selama pengangkutan dan pengapalan. Setelah proses pengeringan selesai, biji kakao kemudian disortasi sesuai dengan tingkatan kelas mutunya, kemudian dikemas untuk menghindari terjadinya kontaminasi baik jamur dan serangga selama proses penyimpanan. Pada proses penyimpanan biji kakao fermentasi kering harus dapat memperhatikan suhu dan kelembaban ruang penyimpanan, karena akan mening- 
katkan kadar air biji kakao yang kemudian akan memberi peluang terhadap jamur untuk tumbuh.

\section{Prioritas Tahapan Pengolahan}

Hasil analisis prioritas dan kontribusi pada setiap tahapan pengolahan pada Tabel 4 menunjukan urutan prioritas tahapan pengolahan yang harus diperhatikan dalam pengolah biji kakao fermentasi untuk dapat memenuhi syarat mutu sesuai Standar Nasional Indonesia (SNI 2323-2008) tentang biji kakao.

Hasil analisa menunjukan bahwa prioritas utama yang harus diperhatikan dalam pengolahan biji kakao fermentasi yaitu penyimpanan biji kakao kering. Hal ini dikarenakan semua atribut seperti yang ditunjukkan pada Tabel 1 dan Tabel 2, yang terdapat pada SNI, biji kakao memiliki hubungan terhadap proses penyimpanan kecuali pada atribut biji kakao slaty, sehingga nilai kontribusi prioritas meningkat pula. Menurut Prabowo dan Zoelangga (2019), bahwa kontribusi prioritas akan menunjukkan seberapa besar suatu karakteristik teknis atau tahapan pengolahan biji kakao mempunyai pengaruh terhadap mutu produk. Semakin besar nilai kontribusinya, maka semakin perlu diprioritaskan.

Prioritas pengolahan selanjutnya setelah penyimpanan yaitu sortasi biji kakao kering (prioritas urutan 4), pengeringan (prioritas urutan 3) dan pengemasan (prioritas urutan 2). Tahapan pengolahan tersebut sangat kuat hubungannya dengan penyimpanan biji kakao (urutan prioritas 1). Sortasi biji kakao kering dilakukan untuk mengurangi kadar biji berkecambah, selanjutnya proses pengeringan akan mempengaruhi kadar air biji kakao yang berkaitan erat dengan kadar biji berjamur. Menurut Amaria et al. (2014) bahwa perkembangan jamur dipengaruhi oleh beberapa faktor, antara lain suhu dan kelembaban, kadar air, aktivitas serangga, dan penanganan pasca panen. Selanjutnya, menurut Ariyanti (2017), peningkatan jumlah jamur tidak terlepas dari kandungan kadar air yang terkandung dalam biji kakao kering. Biji kakao kering yang masih mengandung banyak air akan mudah diserang oleh serangga.

Tahapan selanjutnya yang harus diperhatikan yaitu pada tahap fermentasi biji kakao (urutan prioritas 5), pemecahan buah kakao (urutan prioritas 6), pemeraman atau penyimpanan buah kakao (urutan prioritas 7) dan perendaman dan pencucian biji kakao (urutan prioritas 8). Keempat tahapan pengolahan ini akan mempengaruhi terhadap mutu biji kakao setelah proses fermentasi serta hasil akhir biji kakao setelah dikeringkan. Menurut Amran et al. (2018) pemeraman buah kakao mengakibatkan pulp kakao mudah terlepas sehingga dapat mempermudah proses fermentasi biji kakao. Selanjutnya, pemecahan buah kakao dengan tidak hatihati akan mengakibatkan biji kakao pecah atau terkelupas. Hal ini kemudian akan mengalami kontaminasi silang dan akan lebih cepat membusuk, sehingga akan menggangu proses fermentasi (Utami, 2018). Pencucian dan atau perendaman biji kakao yang telah mendapatkan perlakuan fermentasi bertujuan untuk menghentikan proses fermentasi dan mempermudah proses pengeringan yang disebabkan oleh menipisnya lapisan luar biji kakao (Amran et al., 2018).

Tahapan pascapanen biji kakao yang mendapatkan nilai prioritas urutan terakhir adalah sortasi buah kakao (prioritas urutan 9), sortasi biji kakao basah (prioritas urutan 10), dan pemanenan buah kakao (prioritas urutan 11). Ketiga tahapan pascapanen kakao tersebut berkaitan dengan preparasi biji kakao sebelum dilakukannya proses fermentasi. Mutu biji kakao yang baik berasal dari buah kakao dan preparasi biji kakao yang baik pula. Pemanenan dan sortasi buah kakao berhubungan dengan tingkat kematangan buah yang akan mempengaruhi terhadap kadar biji berkecambah (Marwati et al., 2012), dan buah kakao yang rusak akibat serangan hama. Selanjutnya, sortasi biji kakao basah bertujuan untuk memisahkan biji yang baik dan biji kakao yang telah rusak. Proses sortasi biji kakao basah dilakukan setalah proses pemeraman atau penyimpanan. Menurut Laxiana dan Sugiarto (2018), pemeraman dengan waktu yang lama akan mengakibatkan biji kakao terserang oleh jamur yang menyebabkan biji berwarna hitam, pertumbuhan jamur, serta perkecambahan biji kakao.

\section{SIMPULAN}

Hubungan atribut mutu biji kakao yang dipersyaratkan oleh SNI 2323-2008 rata-rata memiliki nilai hubungan sebesar 2,79 (hubungan kuat) dengan proses pascapanen kakao yaitu pengeringan, pengemasan, dan penyimpanan, rata-rata memiliki nilai hubungan sebesar 2,05 (cukup kuat) den- 
gan pemeraman atau penyimpanan buah kakao, pemecahan buah kakao, fermentasi biji kakao, perendaman dan pencucian biji kakao (setelah difermentasi) dan sortasi biji kakao kering, serta rata-rata memiliki nilai hubungan sebesar 1,45 (mungkin ada hubungan) dengan tahapan pascapanen kakao yaitu pemanenan buah kakao, sortasi buah kakao, dan sortasi biji kakao basah. Hubungan sangat kuat antar proses pengolahan ditunjukkan pada pemanenan buah kakao, pemeraman dan proses fermentasi, pemeraman dan proses fermentasi, pemecahan buah kakao, sortasi biji kakao basah dan fermentasi, fermentasi biji kakao dan perendaman atau pencucian dan pengeringan biji kakao, pengeringan biji kakao, sortasi biji kakao kering, pengemasan dan penyimpanan, sortasi biji kakao kering, pengemasan dan penyimpanan, serta pengemasan dan penyimpanan biji kakao kering. Hasil analisis dengan metode Quality Function Deployment (QFD) menunjukan tahapan proses pengolahan biji kakao fermentasi dengan nilai prioritas tiga tertinggi dari sebelas tahapan pengolahan terdapat pada penyimpanan biji kakao kering dengan nilai prioritas sebesar 27,00, pengeringan biji kakao dengan nilai prioritas sebesar 25,00, dan pengemasan biji kakao kering dengan nilai prioritas sebesar 23,20.

\section{DAFTAR PUSTAKA}

Afriyadi,-R., 2017. Penggunaan quality function deployment (QFD) dalam upaya peningkatan kualitas pelayanan mahasiswa politeknik Sukabumi. STAR, Study and Accounting Research. 11(1), 1-13. http:/ / stiestembi.ac.id/file/7.\%20Rudi.pdf

Amaria, W, Iflah, T, Harni, R. 2014. Dampak Kerusakan oleh Jamur Kontaminan pada Biji Kakao serta Teknologi Pengendaliannya. Bunga Rampai Inovasi Teknologi Bioindustri Kakao. IAARD Press. Jakarta

Amran, Rahim, -I., Darmawan., 2018. Penanganan pasca panen kakao (Theobroma cocoa, L.) pada tingkat petani di desa kalukku, kecamatan kalukku, kabupaten Mamuju. Prosiding Seminar Nasional Sinergitas Multidisiplin Ilmu Pengetahuan dan Teknologi, Makasar. pp. 185-190

Amran, Rahim, A., Darmawan, 2018. PenanAnwar, -S., Jasril., Yunizurwan., Palba, I, -R., 2014. Penerapan metode quality function deployment untuk peningkatan kualitas produk coklat lokal. Seminar Nasional Teknik Industri BKSTI, Jakarta. pp. 79-84

Arief, R, -W., Asnawi, -R., 2011. Karakteristik sifat fisik dan kimia beberapa jenis biji kakao lindak di Lampung. Buletin Ristri. 2(3), 325-330. https://media.neliti.com/ media/publications/196627-ID-karakterisasi-sifat-fisik-dan-kimia-bebe.pdf

Ariyanti, -M., 2017. Karakteristik mutu biji kakao (Theobroma cacao L) dengan perlakuan waktu fermentasi berdasar SNI 2323-2008. Jurnal Industri Hasil Perkebunan. 12(1), 34-42. http://dx.doi. org/10.33104/jihp.v12i1.2757

Badan Standardisasi Nasional. 2008. SNI 23232008, Biji Kakao. Dilihat1 Juli2019. <http:/ / sispk.bsn.go.id/SNI/DetailSNI/7490>

David, -J., Manurung, G, -O., 2014. Perbaikan mutu biji kakao dengan perlakuan suhu pengeringan dan fermentasi di Kalimantan Barat. Prosiding Seminar Nasional Agroinovasi Spesifik Lokasi Untuk Ketahanan Pangan Pada Era Masyarakat Ekonomi ASEAN, Jakarta. pp. 1290-1295.

Dumadi, S, -R., 2011. The moisture content increase of dried cocoa beans during storage at room temperature. Jurnal Imiah Teknologi Energi. 1(12), 45-54. http:/ / ejurnal.bppt. go.id/index.php/JTE/article/view/623

Dursun, -M., Karsak, E, -E., 2013. A QFDbased fuzzy MCDM approach for supplier selection. Applied Mathematical Modelling. 37(8), 5864-5875. https:// doi.org/10.1016/j.apm.2012.11.014

Hayati, -R., Yusmanizar., Mustafril., Fauzi, -H., 2012. Kajian fermentasi dan suhu pengeringan pada mutu kakao (Theobroma cacao L.). Jurnal Keteknikan Pertanian. 26(2), 129-136. https://journal.ipb.ac.id/index. php/jtep/article/view/7430

Iflah, -T., Towaha, -J., 2015. Perbedaan tingkat kematangan buah dan lama fermentasi terhadap kualitas biji kakao. Warta Penelitian dan Pengembangan Tanaman Industri. 21(3), 14-17. http:/ / perkebunan.litbang.pertanian.go.id/ wp-content/uploads/2016/02/perkebunan_Warta-Litbangtri-Des-2015.pdf

Kementerian Perdagangan. 2015. Market intelligence biji kakao dan Produk dari Biji Kakao (HS 1801). Dilihat 1 Juli 2019. < http:/ /itpc. or.jp/wp-content/uploads/2015/12/ Market-Intelligence-2015-Biji-Kakao-danProduk-dari-Biji-Kakao.pdf> 
Kurnianto, M, -F., Ono, -S., Kurniawan, B, P, -Y., 2013. Strategi peningkatan mutu kecap asin berbasis harapan pelanggan (Studi kasus perusahaan kecap asin cap ikan suramas, kecamatan Kaliwates, kabupaten Jember). Jurnal Ilmiah Inovasi. 13(3), 1-13. https:/ / doi. org/10.25047/jii.v13i3.100

Latief, -R., Laga, -A., Muchtar, -M., 2017. Strategi pengendalian mutu proses produksi minuman teh menggunakan metode Six Sigma (studi kasus di PT. Dharana Inti Boga). Jurnal Teknologi Pangan UPN Veteran. 11(2), 62-69. https:/ / doi.org/10.33005/jtp.v11i2.898

Laxiana, -I., Sugiarto, -R., 2018. Fermentasi biji kakao rakyat menggunakan kotak modifikasi dengan variasi lama pemeraman buah. Jurnal Ilmiah Teknologi dan Industri Pangan Unisri. 3(2), 159-165. http:/ / dx.doi.org/10.33061/jitipari.v3i2.2699

Manalu,-R., 2018. Pengolahan biji kakao produksi perkebunan rakyat untuk meningkatkan pendapatan petani. Jurnal Ekonomi dan Kebijakan Publik. 9(2), 99-111. http:/ / dx.doi.org/10.22212/jekp.v9i2.1006

Marwati., Suprapto, -H., Yulianti., 2012. Pengaruh tingkat kematangan terhadap mutu biji kakao (Theobroma cacao L.) yang dihasilkan petani kakao di teluk kedondong bayur Samarinda. Jurnal Teknologi Pertanian Universitas Mulawarman. 8(1), 6-10. https://jtpunmul.files.wordpress. com/2014/02/vol-81-2-marwati.pdf

Munarso, S, -J., 2016. Penanganan pascapanen untuk peningkatan mutu dan daya saing komoditas kakao. Jurnal Penelitian dan Pengembangan Pertanian. 35(3), 111120. http://dx.doi.org/10.21082/jp3. v35n3.2016.p111-120

Nurhadi, -E., Hidayat, S, -I., Indah, P, -N., Widayanti, -S., Harya, G, -I., 2019. Keberlanjutan komoditas kakao sebagai produk unggulan agroindustri dalam meningkatkan kesejahteraan petani. Agroekonomika, Jurnal Sosial Ekonomi dan Kebijakan Pertanian. 8(1), 51-61. https://doi.org/10.21107/ agriekonomika.v8i1.5017

Prabowo, -R., Zoelangga, M, -I., 2019. Pengembangan produk power charger portable dengan menggunakan metode quality function deployment (QFD). Jurnal Rekayasa Sistem Industri. 8(1), 55-62. https:// doi.org/10.26593/jrsi.v8i1.3187.55-62
Sabahannur, -S., Nirwana., Subaedah, -S., 2016. Kajian mutu biji kakao petani di kabupaten Luwu Timur, Soppeng dan Bulukumba. Jurnal Industri Hasil Perkebunan. 11(2), 59-66. http://dx.doi. org/10.33104/jihp.v11i2.3412

Mulato, -S., 2019. Pengembangan teknologi pascapanen pendukung upaya peningkatan mutu kakao nasional. Dilihat 1 Juli 2019. <https:/ / www.cctcid. com/2020/03/23/pengembanganteknologi-pascapanen/>

Sudjarmoko, -B., 2013. "State of the Art" industrialisasi kakao Indonesia. Sirinov 1, 31-42. http:// balittri.litbang.pertanian.go.id/index.php/publikasi/ category/60-sirinov-vol-1-no1\#

Sumanto., Efendi, D, -S., Prastowo, -B., 2015. Peningkatan mutu kakao melalui teknologi bioproses pemerasan pulp (depulping) biji kakao secara mekanis. Jurnal Tanaman Industri dan Penyegar. 2(2), 77-84. http://dx.doi. org/10.21082/jtidp.v2n2.2015.p77-84

Suryaningrat, I, -B., 2016. Implementation of QFD in food supply chain management: A case of processed cassava product in Indonesia. International Journal on Advanced Science, Engineering and Information Technology. 6(3), 302-305. http:// dx.doi.org/10.18517/ijaseit.6.3.713

Tarigan, E, -B., Iflah, -T., 2017. Beberapa komponen fisikokimia kakao fermentasi dan non Fermentasi. Jurnal Agroindustri Halal. 3(1), 48-62. https://doi. org/10.30997/jah.v3i1.687

Utami, R, -R., 2018. Antioksidan biji kakao: pengaruh fermentasi dan penyangraian terhadap perubahannya (ulasan). Jurnal Industri Hasil Perkebunan. 13(2), 75-85. http:/ / dx.doi.org/10.33104/jihp.v13i2.4062

Wajri., Tamrin., 2017. Perbaikan proses pengeringan kakao di desa sungai Langka kecamatan gedung tataan kabupaten Pesawaran. SAKAI SAMBAYAN, Jurnal Pengabdian Kepada Masyarakat. 1, 29-34. http://jss.lppm.unila.ac.id/index.php/ojs/article/view/15

Widyastutik, Arianti, R, -K., 2013. Strategi kebijakan mutu dan standar produk ekspor dalam meningkatkan daya saing (studi kasus produk ekspor biji kakao). Jurnal Manajemen dan Agrobisnis. 10(2), 98-108. https://doi.org/10.17358/ jma.10.2.98-108 